\title{
SPECTROPHOTOMETRIC MICRODETERMINATION OF SOME ANTIHYPERTENSIVE DRUGS IN PURE FORM AND IN PHARMACEUTICAL FORMULATIONS
}

\author{
SAYED A. SHAMA, ALAA S. AMIN *, and HANY OMARA \\ Faculty of Science, Chemistry Department, Benha University, Benha, Egypt. \\ (Received: April 5, 2010 - Accepted: March 23, 2011)
}

\begin{abstract}
Simple, rapid, accurate, precise and sensitive spectrophotometric method for the microdetermination of enalapril maleate (ENM) and lisinopril dihydrate (LIS) has been developed. The method is based on oxidation of the drug by potassium permanganate in acidic medium and determine the unreacted oxidant by measuring the decrease in absorbance for three different acidic dyes; acid red 73 (AR), amaranth dye [acid red 27] (AM) and acid orange 7 (AO) at a suitable $\lambda_{\text {max }}(510$, 521 and $484 \mathrm{~nm}$ for ENM and 509, 521 and $485 \mathrm{~nm}$ for LIS), respectively. Regression analysis of Beer's law plots showed good correlation in the concentration ranges $0.7-12,0.5-7.6$ and $0.6-9.5 \mu \mathrm{g} \mathrm{mL}^{-1}$ and $0.5-9.0,0.4-6.1$ and $0.4-7.2 \mu \mathrm{g} \mathrm{mL}^{-1}$ for ENM and LIS using AR, AM and AO, respectively. The apparent molar absorptivity, Sandell sensitivity, detection and quantitation limits are calculated. Statistical treatment of the results reflects that the proposed procedures are precise, accurate and easily applicable for the determination of ENM and LIS in pure and in pharmaceutical preparations.
\end{abstract}

Keywords: spectrophotometric, enalapril maleate, lisinopril dihydrate, redox reaction, pharmaceutical analysis.

\section{INTRODUCTION}

Enalapril maleate (S)-1-[N-[1-(ethoxycarbonyl)-3-phenylpropy1]-Lalanyl]-L-proline hydrogen maleate and lisinopril dihydrate (S)-1-[N2-(1carboxy-3-phenyl-propyl)-L-lysyl]-L-proline dihydrate are angiotensinconverting enzyme (ACE) has been widely used for the treatment of hypertension and heart failure. The analytical profiles of the two drugs have been reviewed $[1,2]$. Enalapril maleate has been assayed by spectrophotometric [3-7], potentiometric [8,9], HPLC [10-14] and ${ }^{1} \mathrm{H}-\mathrm{NMR}$ [15] methods. In tablets, lisinopril dihydrate has been determined by GC $[16,17]$, spectrophotometric [18-21], colorimetric and fluorimetric [17] procedures. Capillary electrophoresis has been used to separate closely related ACE inhibitors and to quantities them in their pharmaceutical preparations $[22,23]$ and stripping voltammetric method [24]. In biological fluids, enalapril maleate has been quantities by spectrophotometrically [25-27].

Three dyes (AR, AM and AO) are well known for their high absorptivity and have been utilized for estimation of excess oxidant. The present work aims to demonstrate a simple, rapid, accurate, precise and sensitive spectrophotometric method suitable and convenient for the determination of enalapril maleate and lisinopril dihydrate in pure and in dosage forms.

\section{EXPERIMENTAL}

\subsection{Apparatus}

All the spectral measurement were made using JASCO V-530 (UV-VIS) spectrophotometer (Japan), with scanning speed $400 \mathrm{~nm} / \mathrm{min}$ and band width $2.0 \mathrm{~nm}$, equipped with $10 \mathrm{~mm}$ matched quartz cells.

\subsection{Materials and reagents}

All chemicals used were of analytical or pharmacopoeial grade purity and bidistilled water was used. Standard enalapril maleate and lisinopril dihydrate were obtained from Egyptian International of Pharmaceutical Industries Company (EIPICO), $10^{\text {th }}$ of Ramadan City, Egypt.

- Stock enalapril maleate and lisinopril dihydrate solutions $(100 \mu \mathrm{g}$ $\mathrm{mL}^{-1}$ ) were prepared by dissolving $0.01 \mathrm{~g}$ in bidistilled water and adjusted to $100 \mathrm{~mL}$ with water in $100 \mathrm{~mL}$ measuring flask. Working solutions of lower concentration were prepared by serial dilutions.

- Aqueous solutions of $10^{-3} \mathrm{M}$ AR (Aldrich), AM (Merck) and AO (Merck) were prepared by dissolving an appropriate weight in $100 \mathrm{~mL}$ bidistilled water.

- A stock $\left(5.0 \times 10^{-4} \mathrm{M}\right)$ solution of $\mathrm{KMnO}_{4}$ (Aldrich), was freshly prepared by dissolving an accurate weight in $100 \mathrm{~mL}$ measuring flask and diluted to the mark with water, and standardized as recommended [28].

- A stock solution of 2.0 and $0.2 \mathrm{M} \mathrm{H}_{2} \mathrm{SO}_{4}$, was prepared by adding exact volume from stock (98\%) concentrated acid to bidistilled water in $500 \mathrm{~mL}$ measuring flask, and standardized as recorded [29].

\subsection{General procedure}

Aliquot of $0.05-1.2 \mathrm{~mL}$ ENM and $0.04-0.9 \mathrm{~mL}$ LIS $(100 \mu \mathrm{g} \mathrm{mL}-1)$ was added using micropipette to $1.0 \mathrm{~mL}$ of $5.0 \times 10^{-4} \mathrm{M} \mathrm{KMnO}_{4}$ containing 1.0 $\mathrm{mL}(0.2 \mathrm{M}) \mathrm{H}_{2} \mathrm{SO}_{4}$ for ENM and $0.5 \mathrm{~mL}(2.0 \mathrm{M}) \mathrm{H}_{2} \mathrm{SO}_{4}$ for LIS. The solution was heated in a water bath at $60 \pm 1$ and $80 \pm 1{ }^{\circ} \mathrm{C}(10 \mathrm{~min})$ for ENM and LIS, respectively. The mixtures were cooled and $0.5,0.6$ and $0.8 \mathrm{~mL}$ of $10^{-3} \mathrm{M} \mathrm{AR}$, $\mathrm{AM}$ and $\mathrm{AO}$, respectively were added for ENM and $0.35,0.6$ and $0.8 \mathrm{~mL}$ of $10^{-3} \mathrm{M}$ AR, AM and AO, respectively were added for LIS. The volume was completed to $10 \mathrm{~mL}$ with bidistilled water. The decrease in color intensity of dye was measured spectrophotometrically against a blank solution containing the same constituent except drug treated similarly. The concentration range was determined in each case by plotting the concentration of ENM and LIS against absorbance at the corresponding maximum wavelengths.

The standard deviations of the absorbance measurements were calculated from a series of 13 blank solution. The limits of detection $(\mathrm{K}=3)$ and of quantification $(\mathrm{K}=10)$ of the method were established [30] and recorded in Table 1, according to the IUPAC definitions $\left(\mathrm{C}_{1}=\mathrm{KS} / \mathrm{s}\right.$ where $\mathrm{C}_{1}$ is the limit of detection, $\mathrm{S}_{\mathrm{o}}$ is the standard error of blank, $\mathrm{s}$ is the slope of the standard curve and $\mathrm{K}$ is the constant related to the confidence interval). The relative standard deviation was ${ }^{3} 0.72 \%$ obtained from a series of 10 standards each containing $5.0 \mu \mathrm{g} \mathrm{mL}^{-1}$ of the studied drugs.

\subsection{Stoichiometric relationship}

The stoichiometry of [Oxidant]/[Dye] at the selected conditions was carried out. The oxidant was kept constant and variable concentrations of dye $\left(10^{-3} \mathrm{M}\right)$ were added and $5.0 \mu \mathrm{g} \mathrm{mL} \mathrm{m}^{-1}$ of both drug. The absorbance values were then plotted against the molar ratio [Oxidant]/[Dye].

The stoichiometry of the reaction between drugs and the oxidant at the selected conditions was established by the molar ratio method. In this method $1.0 \mathrm{~mL}$ of $5.0 \times 10^{-4} \mathrm{M} \mathrm{KMnO}_{4}$ is kept constant and variable concentrations of drugs $\left(5.0 \times 10^{-4} \mathrm{M}\right)$ were added. The absorbance was measured at $\lambda_{\max }$ against blank solution prepared in the same manner. The absorbance values were then plotted against the molar ratio [Dye]/[Oxidant].

\subsection{Procedure for tablets}

At least ten tablets of ENM and LIS were weighed, powdered and mixed well. A portion equivalent to $10 \mathrm{mg}$ was weighed and suspended in $100 \mathrm{~mL}$ bidistilled water, mixed well for $15 \mathrm{~min}$ using a magnetic stirrer and filtered through a sintered glass crucible $\mathrm{G}_{4}$. A $0.5 \mathrm{~mL}$ aliquot of the test solution (100 $\mu \mathrm{g} \mathrm{mL}{ }^{-1}$ of ENM and LIS) were treated as described above.

\section{RESULTS AND DISCUSSION}

An analytical procedure based on the specific reactivity of a secondary amino group in ENM and a primary as well as a secondary amino group in LIS were investigated. The suggested mechanism $[31,32]$ is: 
$\mathrm{KMnO}_{4}+\mathrm{H}^{+}+$drug oxidation products of drug $+\mathrm{KMnO}_{4}$ (excess)

$\mathrm{KMnO}_{4}$ (excess) + dye oxidative dye (colorless products)

and determine the unreacted oxidant by measuring the decrease in absorbance of dyes at their $\lambda_{\max }$ as shown in (Figures 1,2).

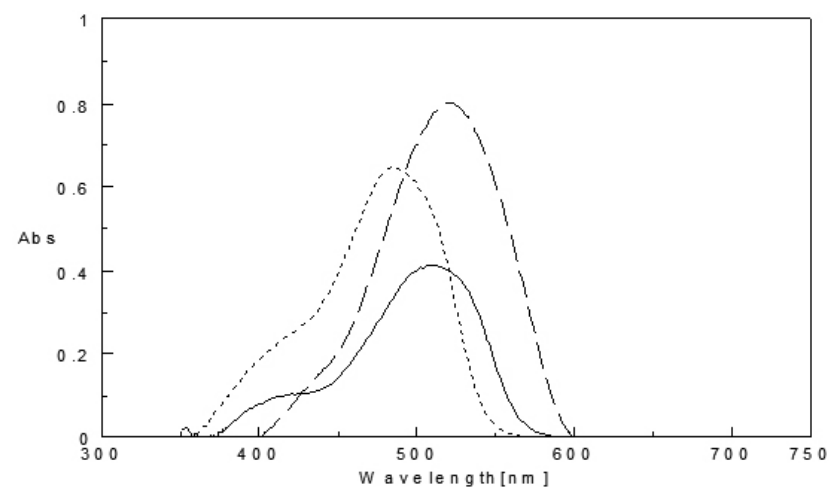

Figure 1. Absorption spectra for the reaction product of $5.0 \mu \mathrm{g} \mathrm{mL}^{-1}$ of enalapril maleate with $\mathrm{KMnO}_{4}\left(5.0 \times 10^{-4} \mathrm{M}\right)$ and $\left(1.0 \times 10^{-3} \mathrm{M}\right)$ dyes $(\ldots .$. for $\mathrm{AO}$,--- for $\mathrm{AM}$, and - for $\mathrm{AR})$.

\subsection{Optimization}

The influence of each of the following variables on the reaction was tested to reach the maximum color intensity.

\section{1- Effect of permanganate concentration}

The influence of $\mathrm{KMnO}_{4}$ concentration was studied in the range from $10^{-5}$ $-10^{-4} \mathrm{M}$, as final concentration. The optimum condition was found to be $5.0 \mathrm{x}$ $10^{-5} \mathrm{M}$; higher concentration of $\mathrm{KMnO}_{4}$ caused the color to disturbed.

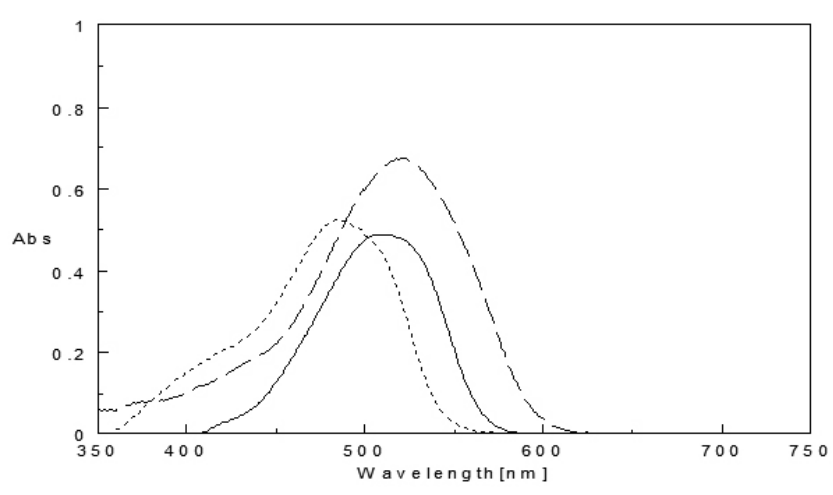

Figure 2. Absorption spectra for the reaction product of $5.0 \mu \mathrm{g} \mathrm{mL} \mathrm{m}^{-1}$ of lisinopril dihydrate with $\mathrm{KMnO}_{4}\left(5.0 \times 10^{-4} \mathrm{M}\right)$ and $\left(1.0 \times 10^{-3} \mathrm{M}\right)$ dyes $(\ldots .$. for $\mathrm{AO},----$ for $\mathrm{AM}$, and for AR).

\section{2- $\quad$ Effect of acid concentration}

Different types of acid were examined $\left(\mathrm{H}_{2} \mathrm{SO}_{4}, \mathrm{H}_{3} \mathrm{PO}_{4}\right.$ and $\left.\mathrm{CH}_{3} \mathrm{COOH}\right)$. The most suitable acid to achieve maximum yield of redox reaction was found to be sulphuric acid. Moreover, various volumes of $\mathrm{H}_{2} \mathrm{SO}_{4}$ were tested and found to be $1.0 \mathrm{~mL}(0.2 \mathrm{M}), 0.5 \mathrm{~mL}(2.0 \mathrm{M})$ for ENM and LIS, respectively as shown in (Figure 3).

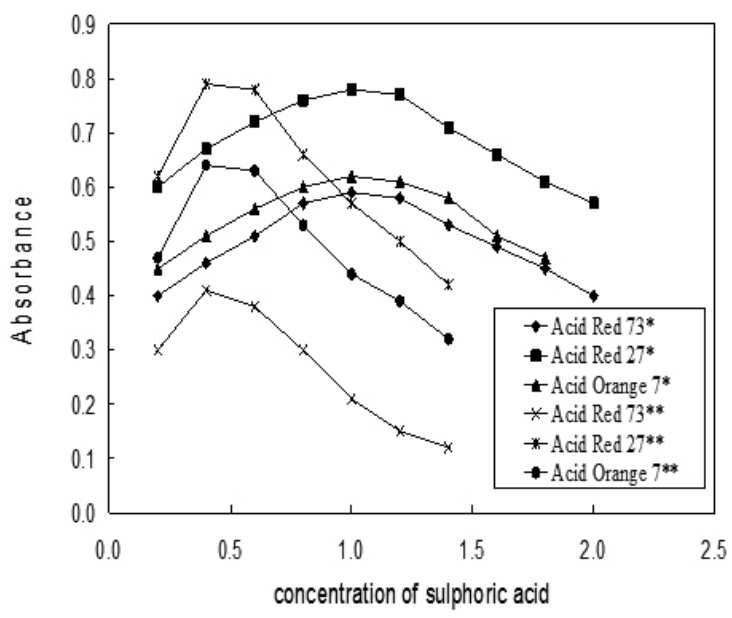

Figure 3. Effect of $\mathrm{mL}$ added of sulphuric acid $[0.2 \mathrm{M} \& 2.0 \mathrm{M}$ for ENM (*) and LIS (**), respectively] on absorbance of $5.0 \mu \mathrm{g} \mathrm{mL} \mathrm{m}^{-1}$ of drug with $\mathrm{KMnO}_{4}\left(5.0 \times 10^{-4} \mathrm{M}\right)$ and dyes $\left(1.0 \times 10^{-3} \mathrm{M}\right)$.

\section{3- $\quad$ Effect of temperature and time}

The oxidation process of ENM and LIS is initiated by heating in water bath at $60 \pm 1$ and $80 \pm 1{ }^{\circ} \mathrm{C}$, respectively since the results are highly concordant at these temperatures. The time required to complete the reaction was $10 \mathrm{~min}$. After oxidation process, the solution must be cooled at least for $3.0 \mathrm{~min}$ before addition of the dye.

\section{4- Effect of dye concentration}

The optimum volumes of the dye used for production of maximum color intensity were $0.5,0.6$ and $0.8 \mathrm{~mL}\left(10^{-3} \mathrm{M}\right)$ of $\mathrm{AR}, \mathrm{AM}$ and $\mathrm{AO}$, respectively were added for ENM and $0.35,0.6$ and $0.8 \mathrm{~mL}\left(10^{-3} \mathrm{M}\right)$ of AR, AM and $\mathrm{AO}$, respectively were added for LIS. The effect of time after the addition of dye indicated that shaking for $2.0 \mathrm{~min}$ was sufficient to give reliable results for all dyes. The color of product remains constant for at least $48 \mathrm{~h}$.

\subsection{Stoichiometric ratio}

The stoichiometry of [Oxidant]/[Dye] at the selected conditions showed that the inflection of the two straight lines at 1.0, 0.83 and 0.63 for ENM, $1.25,0.83$ and 0.83 for LIS in case of AR, AM and AO, respectively. Thus the stoichiometric ratio of oxidant to dye are $1.0: 1.0,1.0: 1.2,1.0: 1.59$ for ENM, $1.0: 0.8,1.0: 1.2$ and $1.0: 1.2$ for LIS in case of AR, AM and AO, respectively as shown in (Figure 4).

$\mathrm{KMnO}_{4}$ reacts with drugs with consumption of $0.77,0.37$ and 0.47 (for ENM) and $0.43,0.32$ and 0.41 (for LIS) moles of $\mathrm{KMnO}_{4}$ per each mole of drugs. Thus molar ratios of [Dye]/[Oxidant] are $1.0: 1.3,1.0: 1.27$ and 1.0 : 2.13 (for ENM), $1.0: 2.33,1.0: 3.13$ and $1.0: 2.44$ (for LIS) in case of AR, $\mathrm{AM}$ and $\mathrm{AO}$, respectively. These ratios indicated that the oxidation process was depended on the chemical structure of the studied drugs and different degradation products was obtained. 


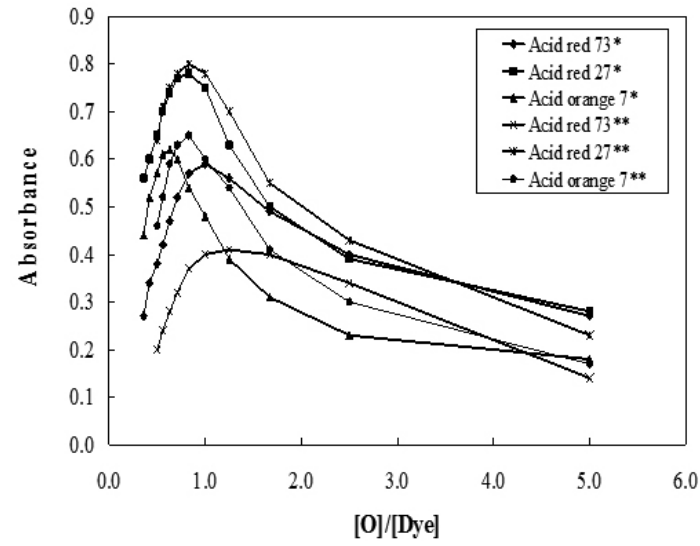

Figure 4. Molar ratio method [Oxidant]/[Dye] for $5.0 \mu \mathrm{g} \mathrm{ml}{ }^{-1}$ of ENM (* and LIS (**) with $\mathrm{KMnO}_{4}\left(5.0 \times 10^{-4} \mathrm{M}\right)$ and dyes $\left(1.0 \times 10^{-3} \mathrm{M}\right)$.

\subsection{Quantification}

Beer's law limits, molar absorptivity, Sandell sensitivity, regression equations and correlation coefficients were calculated and recorded in Table 1. The limits of detection and quantitation were established according to IUPAC definitions [30] and recorded in Table 1.

Table 1.- Optical and regression characteristics of ENM and LIS with three dyes.

\begin{tabular}{|l|c|c|c|c|c|c|}
\hline \multirow{2}{*}{\multicolumn{1}{|c|}{ Parameters }} & \multicolumn{3}{|c|}{ ENM } & \multicolumn{2}{c|}{ LIS } \\
\cline { 2 - 7 } & $\mathrm{AR}$ & $\mathrm{AM}$ & $\mathrm{AO}$ & $\mathrm{AR}$ & $\mathrm{AM}$ & $\mathrm{AO}$ \\
\hline$\lambda_{\text {max }} ; \mathrm{nm}$ & 510 & 521 & 484 & 509 & 521 & 485 \\
\hline Bear's law limits; $\mu \mathrm{g} \mathrm{mL}^{-1}$ & $0.7-12$ & $0.5-7.6$ & $0.6-9.5$ & $0.5-9.0$ & $0.4-6.1$ & $0.4-7.2$ \\
\hline Ringbom limits; $\mu \mathrm{g} \mathrm{mL}^{-1}$ & $0.9-11.2$ & $0.6-7.2$ & $0.8-9.1$ & $0.6-8.7$ & $0.6-5.8$ & $0.5-7.0$ \\
\hline Molar absorptivity; $\mathrm{L} \mathrm{mol}^{-1} \mathrm{~cm}^{-1}$ & $4.96 \times 10^{4}$ & $6.49 \times 10^{4}$ & $5.09 \times 10^{4}$ & $3.82 \times 10^{4}$ & $7.10 \times 10^{4}$ & $5.76 \times 10^{4}$ \\
\hline Sandell sensitivity; $\mathrm{ng} \mathrm{cm}^{-2}$ & 9.93 & 7.59 & 9.68 & 11.55 & 6.22 & 7.67 \\
\hline Detection limits; $\mu \mathrm{g} \mathrm{mL}^{-1}$ & 0.197 & 0.138 & 0.147 & 0.116 & 0.092 & 0.101 \\
\hline Quantitation limits; $\mu \mathrm{g} \mathrm{Ml}^{-1}$ & 0.658 & 0.460 & 0.489 & 0.386 & 0.308 & 0.336 \\
\hline $\begin{array}{l}\text { Regression equation": } \\
\text { Slope (b) }\end{array}$ & 0.1007 & 0.1317 & 0.1033 & 0.0866 & 0.1609 & 0.1304 \\
\hline Intercept (a) & -0.0166 & -0.0098 & -0.0006 & -0.0137 & -0.0031 & -0.0017 \\
\hline Correlation coefficient (r) & 0.9998 & 0.9998 & 0.9995 & 0.9996 & 0.9997 & 0.9996 \\
\hline RSD; \% & 0.58 & 0.44 & 0.61 & 0.49 & 0.28 & 0.72 \\
\hline Recovery; \% & $99.2 \pm 0.7$ & $100.4 \pm 0.9$ & $99.6 \pm 1.0$ & $99.3 \pm 1.2$ & $99.4 \pm 1.1$ & $100.2 \pm 1.2$ \\
\hline Stiochiometric ratio $[\mathrm{O} /[\mathrm{D}]$ & $1.0: 1.0$ & $1.0: 1.2$ & $1.0: 1.59$ & $1.0: 0.8$ & $1.0: 1.2$ & $1.0: 1.2$ \\
\hline Stiochiometric ratio $[\mathrm{D}] /[\mathrm{O}]$ & $1.0: 1.3$ & $1.0: 2.0$ & $1.0: 2.13$ & $1.0: 2.33$ & $1.0: 3.13$ & $1.0: 2.44$ \\
\hline
\end{tabular}

*With respect to $\mathrm{A}=\mathrm{a}+\mathrm{bC}$ where $\mathrm{C}$ is concentration of drug in $\mu \mathrm{g} \mathrm{mL} \mathrm{m}^{-1}$ and $\mathrm{A}$ is absorbance.

In order to determine the accuracy and precision of the methods, solutions containing three different concentrations of ENM and LIS were prepared and analyzed in six replicates. The analytical results obtained from this investigation were summarized in Table 2 . The effect of excipients frequently found in formulations [33], such as glucose, lactose, fructose, calcium hydrogen phosphate, magnesium stearate and starch was evaluated using the proposed method, the excipients in all tablets are not interfere for both drugs.

Table 2.- Evaluation of the accuracy and precision of the proposed procedure.

\begin{tabular}{|c|c|c|c|c|c|}
\hline Ion pair & $\begin{array}{c}\text { Taken } \\
\mu \mathrm{g} \mathrm{mL}\end{array}$ & $\underset{\%}{\text { Recovery a }}$ & $\underset{\%}{\mathrm{RSD}^{\mathrm{a}}}$ & $\begin{array}{l}\mathrm{RE} \\
\%\end{array}$ & Confidence limits ${ }^{b}$ \\
\hline AR-ENM & $\begin{array}{l}5.0 \\
6.0 \\
7.0\end{array}$ & $\begin{array}{l}98.6 \\
99.7 \\
100.1\end{array}$ & $\begin{array}{l}0.45 \\
0.52 \\
0.57\end{array}$ & $\begin{array}{l}0.47 \\
0.54 \\
0.60\end{array}$ & $\begin{array}{l}4.93 \pm 0.0230 \\
5.98 \pm 0.0325 \\
7.01 \pm 0.0420\end{array}$ \\
\hline AM-ENM & $\begin{array}{l}5.0 \\
6.0 \\
7.0\end{array}$ & $\begin{array}{l}100.6 \\
99.2 \\
97.1\end{array}$ & $\begin{array}{l}0.38 \\
0.49 \\
0.54\end{array}$ & $\begin{array}{l}0.40 \\
0.51 \\
0.57\end{array}$ & $\begin{array}{l}5.03 \pm 0.0200 \\
5.95 \pm 0.0304 \\
6.80 \pm 0.0390\end{array}$ \\
\hline AO-ENM & $\begin{array}{l}5.0 \\
6.0 \\
7.0\end{array}$ & $\begin{array}{l}97.6 \\
98.8 \\
100.4\end{array}$ & $\begin{array}{l}0.59 \\
0.69 \\
0.43\end{array}$ & $\begin{array}{l}0.62 \\
0.73 \\
0.45\end{array}$ & $\begin{array}{l}4.88 \pm 0.0304 \\
5.93 \pm 0.0430 \\
7.03 \pm 0.0315\end{array}$ \\
\hline AR-LIS & $\begin{array}{l}4.0 \\
5.0 \\
6.0\end{array}$ & $\begin{array}{l}100.3 \\
99.6 \\
99.0\end{array}$ & $\begin{array}{l}1.00 \\
0.99 \\
0.93 \\
\end{array}$ & $\begin{array}{l}1.05 \\
1.04 \\
0.97\end{array}$ & $\begin{array}{l}4.01 \pm 0.0421 \\
4.98 \pm 0.0518 \\
5.94 \pm 0.0577 \\
\end{array}$ \\
\hline AM-LIS & $\begin{array}{l}4.0 \\
5.0 \\
6.0\end{array}$ & $\begin{array}{l}100.8 \\
97.2 \\
100.3 \\
\end{array}$ & $\begin{array}{l}0.82 \\
0.80 \\
0.70\end{array}$ & $\begin{array}{l}0.86 \\
0.84 \\
0.73 \\
\end{array}$ & $\begin{array}{l}4.03 \pm 0.0348 \\
4.86 \pm 0.0410 \\
6.02 \pm 0.0441\end{array}$ \\
\hline AO-LIS & $\begin{array}{l}4.0 \\
5.0 \\
6.0\end{array}$ & $\begin{array}{l}99.5 \\
98.2 \\
98.3\end{array}$ & $\begin{array}{l}0.72 \\
0.70 \\
0.64\end{array}$ & $\begin{array}{l}0.75 \\
0.74 \\
0.67\end{array}$ & $\begin{array}{l}3.98 \pm 0.0300 \\
4.91 \pm 0.0362 \\
5.90 \pm 0.0396\end{array}$ \\
\hline
\end{tabular}

a Relative standard deviation for six determinations

b $95 \%$ confidence limits and five degrees of freedom 
3.4. Analytical applications

The proposed method was successfully applied to determine ENM and LIS in their dosage forms. The results obtained were compared statistically by Student's t-test (for accuracy), and variance ratio F-test (for precision) [32], with the official method [35] for ENM and [36] for LIS at 95\% confidence level as recorded in Table 3.

Table 3.- Determination of ENM and LIS in pharmaceutical formulations using the proposed and official methods.

\begin{tabular}{|c|c|c|c|c|c|c|c|c|c|c|}
\hline \multirow{2}{*}{$\begin{array}{c}\text { Dosage } \\
\text { forms }\end{array}$} & \multicolumn{3}{|c|}{ AP } & \multicolumn{4}{|c|}{$\mathrm{AM}$} & \multicolumn{2}{|c|}{ AO } & Official \\
\hline & $\mathrm{R} \%$ & t-value & F-ratio* & $\mathrm{R} \%$ & t-value ${ }^{*}$ & F- ratio* & R \% & t-value ${ }^{*}$ & F-ratio* & R \% \\
\hline $\begin{array}{l}\text { Acapril } \\
5 \mathrm{mg}^{(1)}\end{array}$ & 99.3 & 0.28 & 1.71 & 99.7 & 0.54 & 1.94 & 99.5 & 0.84 & 2.39 & 99.4 \\
\hline $\begin{array}{c}\text { Ezapril } \\
10 \mathrm{mg}{ }^{(2)}\end{array}$ & 99.4 & 0.64 & 2.47 & 99.7 & 0.24 & 1.64 & 99.3 & 0.19 & 1.71 & 98.7 \\
\hline $\begin{array}{l}\text { Enalapril } \\
10 \mathrm{mg}^{(3)}\end{array}$ & 100.3 & 0.38 & 2.28 & 99.4 & 0.81 & 2.24 & 99.8 & 0.19 & 1.89 & 98.9 \\
\hline $\begin{array}{l}\text { Lisopril } \\
10 \mathrm{mg}^{(4)} \\
\end{array}$ & 99.5 & 0.87 & 2.38 & 100.6 & 1.29 & 2.58 & 100.1 & 0.89 & 1.97 & 98.9 \\
\hline $\begin{array}{l}\text { Sinopril } \\
10 \mathrm{mg}^{(5)}\end{array}$ & 100.2 & 0.60 & 2.27 & 99.4 & 0.85 & 2.24 & 99.9 & 0.19 & 1.89 & 98.8 \\
\hline $\begin{array}{c}\text { Zestril } \\
10 \mathrm{mg}^{(6)}\end{array}$ & 99.8 & 0.78 & 1.67 & 100.3 & 0.55 & 1.87 & 99.7 & 0.47 & 2.16 & 99.2 \\
\hline
\end{tabular}

${ }^{*}$ Theoretical value for $\mathrm{t}$ - and $\mathrm{F}$ - values for five degrees of freedom and $95 \%$ confidence limits are 2.57 and 5.05 , respectively.

(1) Alpha Chem Advanced Pharmaceutical Industries Company (ACAPI), Bader Industrial City, Cairo, Egypt.

(2) El-Kahira Pharmaceutical and Chemical Industries Company, Cairo, Egypt.

(3) Egyptian International of Pharmaceutical Industries Company (EIPICO), $10^{\text {th }}$ of Ramadan City, Egypt.

(4) Hi-Pharm for Manufactured Pharmaceuticals Company, El-Obour city, Cairo, Egypt.

(5) Global Napi Pharmaceuticals Company (GNP) under license from Merck \& Co. Inc. USA, Egypt.

(6) South Egypt Drug Industries Company (SEDICO), 6 October City, Egypt under license of ZENECA Limited, England.

The results showed that the $\mathrm{t}$ - and F- values were lower than the critical values indicating that there was no significant difference between the proposed and official methods. The proposed method was more accurate with high recoveries compared to the official method (dissolve $0.1 \mathrm{~g}$ of ENM in carbon dioxide-free water and diluted to $30 \mathrm{~mL}$ with the same solvent, titrate with $0.1 \mathrm{M}$ sodium hydroxide, determine the end-point potentiometrically. Titrate up to the second point of inflection. $1.0 \mathrm{~mL}$ of $0.1 \mathrm{M}$ sodium hydroxide is equivalent to $16.42 \mathrm{mg}$ of $\left[\mathrm{C}_{24} \mathrm{H}_{32} \mathrm{~N}_{2} \mathrm{O}_{9}\right.$ ] [35], and (dissolve $0.35 \mathrm{gm}$ of LIS in $50 \mathrm{~mL}$ of bidistilled water, titrate with $0.1 \mathrm{M}$ sodium hydroxide, and determine the end-point potentiometrically. $1.0 \mathrm{~mL}^{2}$ of $0.1 \mathrm{M}$ sodium hydroxide is equivalent to $40.55 \mathrm{mg}$ of [ $\mathrm{C}_{21} \mathrm{H}_{31} \mathrm{~N}_{3} \mathrm{O}_{5}$ ] [36], so the proposed method can be recommended for routine analysis of ENM and LIS in pure and dosage forms in the majority of drug quality control laboratories.

\section{CONCLUSION}

The proposed method was advantageous over other reported visible spectrophotometric and colorimetric methods [25, 37-41], related to their high reproducibility, high sensitivity, less time consuming and using simple and inexpensive reagents. Moreover, this method allowed the determination of both drugs up to $0.4 \mu \mathrm{g} \mathrm{mL}$, in addition to simplicity, rapidity, precision and stability of colored species for more than $48 \mathrm{~h}$. The proposed method may be applied for routine analysis and in quality control laboratories for the quantitative determination of the ENM and LIS in raw materials and in pharmaceutical formulations.

Table 2. Comparison of reagents for spectrophotometric determination of ENM and LIS.

\begin{tabular}{|c|c|c|c|c|c|}
\hline Reagent & Medium & $\begin{array}{l}\lambda_{\max } \\
(\mathrm{nm})\end{array}$ & $\begin{array}{c}\mathrm{e} \times 10^{-4} \\
\mathrm{~L} \mathrm{~mol}^{-1} \mathrm{~cm}^{-1}\end{array}$ & $\begin{array}{l}\text { Linear range } \\
\left(\mu \mathrm{g} \mathrm{mL} L^{-1}\right)\end{array}$ & Ref. \\
\hline $\mathrm{Mo}(\mathrm{V})$ and thiocyanate & chloroform & 517 & 2.00 & $4.0-36$ & [37] \\
\hline $\mathrm{Mo}(\mathrm{V})$ and thiocyanate ${ }^{*}$ & benzalkonium chloride & 545 & 5.0 & $3.0-27$ & [37] \\
\hline $\mathrm{KIO}_{3}$ and iodide $\mathrm{KI}^{*}$ & $\mathrm{H}_{2} \mathrm{O}$ & 325 & 2.2 & $2.5-50$ & [38] \\
\hline $\mathrm{KMnO}_{4+} \mathrm{AR}^{*}$ & $\mathrm{H}_{2} \mathrm{SO}_{4}$ & 510 & 4.96 & $0.7-12$ & \multirow{3}{*}{$\begin{array}{l}\text { This } \\
\text { work }\end{array}$} \\
\hline $\mathrm{KMnO}_{4+} \mathrm{AM}^{*}$ & $\mathrm{H}_{2} \mathrm{SO}_{4}$ & 521 & 6.49 & $0.5-7.6$ & \\
\hline $\mathrm{KMnO}_{4+} \mathrm{AO}^{*}$ & $\mathrm{H}_{2} \mathrm{SO}_{4}$ & 484 & 5.09 & $0.6-9.5$ & \\
\hline 1-fluoro-2,4-dinitrobenzene ${ }^{* *}$ & acetonitrile & 405.5 & 0.323 & $8.0-120$ & [25] \\
\hline 2, 3-dichloro 5, 6-dicyano 1, 4-benzoquinone ${ }^{* *}$ & 1, 4-dioxan. & 565 & 0.76 & $20-560$ & {$[38]$} \\
\hline N-bromosuccinimide ${ }^{* *}$ & acetone & 353 & 0.14 & $10-200$ & [39] \\
\hline Chloranil $^{* *}$ & $\begin{array}{l}\text { 1,4-dioxan } \\
\text { acetonitrile }\end{array}$ & 462 & 0.0728 & $24-600$ & [39] \\
\hline ninhydrin $^{* *}$ & DMF. & 600 & 0.482 & $10-150$ & [40] \\
\hline ninhydrin $^{* *}$ & bicarbonate & 420 & 0202 & $5.0-50$ & {$[41]$} \\
\hline $\mathrm{KMnO}_{4+} \mathrm{AR}^{* *}$ & $\mathrm{H}_{2} \mathrm{SO}_{4}$ & 509 & 3.82 & $0.5-9.0$ & \multirow{3}{*}{$\begin{array}{l}\text { This } \\
\text { work }\end{array}$} \\
\hline $\mathrm{KMnO}_{4+} \mathrm{AM}^{* *}$ & $\mathrm{H}_{2} \mathrm{SO}_{4}$ & 521 & 7.10 & $0.4-6.1$ & \\
\hline $\mathrm{KMnO}_{4+} \mathrm{AO}^{* *}$ & $\mathrm{H}_{2} \mathrm{SO}_{4}$ & 485 & 576 & $0.4-7.2$ & \\
\hline
\end{tabular}




\section{REFERENCES}

[1] I. P. Dominic, S. B. Gerald, Enalapril, in: Florey K (Ed.), "Analytical profiles of Drugs Substances", Academic Press, New York, 16, 1987, 207.

[2] I.P. Dominic, J. D. DeMarco, A. B. Marvin, Lisinopril, in: Florey K (Ed.), "Analytical Profiles of Drugs Substances", Academic Press, New York, 21, 1992, 233.

[3] T. Kato, Anal. Chim. Acta 175, 339, (1985).

[4] S. M. Blaih, H. H. Abdine, F. A. El-Yazbi, R. A. Shaalan, Spectrosc. Lett. 33, 91, (2000).

[5] A. S. Dhake, V. S. Kasture, M. R. Sayed, Indian Drugs 39, 14, (2002).

[6] M. M. Ayad, A. A. Shalaby, H. E. Abd-Ellatif, M. M. Hosny, J. Pharm. \& Biomed. Anal. 28, 311, (2002).

[7] A. A. Nawal, Anal. Sci. 19, 1145, (2003).

[8] H. Y. Aboul-Enein, A. A. Bunaciu, C. Bala, S. Fleschin, Anal. Lett. 30, 1999, (1997).

[9] H. Y. Aboul-Enein, R. I. Stefan, J. F. Van Staden, Analusis 27, 53, (1999).

[10] Q. Gu, X. Chen, D. Zhong, Y. Wang, J. Chromatog. B 25, 337, (2004).

[11] R. T. Sane, A. J. Vaidya, J. K. Ghadge, A. B. Jani, A. K. Kotwal, Indian Drugs 29, 244, (1992).

[12] E. Anzenbacherova, P. Anzenbacher, K. Macek, J. Kvetina, J. Pharm. \& Biomed. Anal. 24 (2001) 1151.

[13] B. Atanisz, J. Pharm. \& Biomed. Anal. 31, 375, (2003).

[14] J. Lee, J. Son, M. J. Lee, K. T. Lee, D. H. Kim, Rapid Commun. Mass Spectrom. 17 (2003) 1157.

[15] A. Zoppi, M. Linares, M. Longhi, J. Pharm. \& Biomed. Anal. 37, 627, (2005).

[16] A. B. Avadhanulu, A. R. Pantulu, Indian Drugs 30, 646, (1993).

[17] B. M. Tashtoush, F. Q. Technol, N. M. Najib, Pharmazie 59, 21, (2004).

[18] F. A. El-Yazbi, H. H. Abdine, R. A. Shaalan, J. Pharm. \& Biomed. Anal. 19, 819, (1999).

[19] D. Ozer, H. Senel, J. Pharm. \& Biomed. Anal. 21, 691, (1999).

[20] A. A. El-Emam, S. H. Hansen, M. A. Mostafa, S. M. El-Ashry, D. T. ElSherbiny, J. Pharm. \& Biomed. Anal. 34, 35, (2004).

[21] N. Rahman, N. Anwar, M. Kashif, IL Farmaco 60, 605, (2005).
[22] R. Gotti, V. Andrisano, V. Cavrini, C. Bertucci, S. Fulanetto, J. Pharm. \& Biomed. Anal. 22, 423, (2000)

[23] S. Hillaert, Y. H. Vander, W. V. Bossche, J. Chromatogr. 978, 231, (2003).

[24] O. A. Razak, S. F. Belal, M. M. Bedair, R. S. Haggag, Talanta 59, 1061, (2003).

[25] G. Paraskevas, J. A. Politou, M. Koupparis, J. Pharm. \& Biomed. Anal. $29865,(2002)$

[26] A. El-Gindy, A. Ashour, L. Abdel-Fattah, M. Shabana, J. Pharm. \& Bioned. Anal. 25, 913, (2001).

[27] O. Abdel Razak, S. F. Belal, M. M. Badair, N. S. Barakat, R. S. Haggag, J. Pharm. Biomed Anal. 31, 701, (2003).

[28] J. Basset, R. C. Denney, G. H. Jeffery, J. Mendham, "Vogels Text Book of Quantitative Inorganic Analysis" 4" Ed. 350, 1986.

[29] J. Basset, G. H. Jeffery, J. Mendham, "Vogels Text Book of Quantitative Inorganic Analysis", I, 308, 1978.

[30] IUPAC. Spectrochim. Acta B 33, 242, (1978).

[31] S. A. Shama, A. S. Amin, E. M. Mabrouk, H. A. Omara, Arab. J. Chem., $2,95,(2009)$

[32] S. A. Shama, A. S. Amin, H. Omara, J. Quan. Spect. \& Rad. Trans. 102, $261,(2006)$.

[33] I. P. Dominic, G. S. Brenner, Analytical Profiles Drug Substances, Academic Press, New York, 21, 233, 1992.

[34] J. C. Miller, J. N. Miller, "Statistics in Analytical Chemical", $3^{\text {rd }}$ Edn., Ellis Horwood, Chichester, 1993.

[35] The British Pharmacopoeia (BP), Her Majesty's Stationary Office, London, I, 693, 2003.

[36] The British Pharmacopoeia (BP), Her Majesty's Stationary Office, London, I, 1136, 2003.

[37] M. M. Baraka, M. EL-Sadek, E. M. M. Moussa, N. M. A. Abd-Alaty, Chem. Pharm. Bull. 56, 1521, (2008).

[38] N. Rahman, S.M. Haque, Anal. Chem. Insights, 3, 31, (2008).

[39] N. Rahman, M. R. Siddiqui, S. N. H. Azmi, Chem. Anal. (Warsaw), 52, 465 (2007)

[40] A. Raza, T. M. Ansari, A. Rehman, J. Chin. Chem. Soc., 52, 1055, (2005).

[41] K. Basavaiah, K. Tharpa, S. G. Hiriyanna, K. B. Vinay, J. Food \& Drug Anal., 17, 93, (2009). 